\title{
COMMENTS
}

\section{Parental Control of a Minor's Right to Sue in Federal Court}

\author{
Alison M. Brumley $\dagger$
}

The legal status of minors relative to their parents and the state is ambiguous. The Supreme Court has accorded extensive, though not full, constitutional rights to minors. The Court has stated that "[c]onstitutional rights do not mature and come into being magically only when one attains the state-defined age of majority. Minors, as well as adults, are protected by the Constitution and possess constitutional rights." At the same time, the Court has acknowledged that parents have broad discretion in child rearing: parental control of children is "an important interest that 'undeniably warrants deference and, absent a powerful countervailing interest, protection." "2 When a minor wishes to assert her constitutional rights in the face of parental disapproval, the state thus faces a dilemma. The state's right to regulate minors' behavior and its duty to help enforce parental authority ${ }^{3}$ must be reconciled with its duty to protect the constitutional rights of all its citizens, including children. ${ }^{4}$

$\dagger$ B.S., University of Southwestern Louisiana, 1983; J.D. Candidate 1991, The University of Chicago.

2 Planned Parenthood of Central Missouri v Danforth, 428 US 52, 74 (1976).

2 Lassiter v Dept. of Social Services, 452 US 18, 27 (1981), quoting Stanley v Illinois, 405 US 645, 651 (1972).

s See, for example, H.L. v Matheson, 450 US 398, 411-13 (1981) (Utah statute requiring notification, "if possible," of parents of minor child seeking abortion serves important state interest); Ginsburg v New York, 390 US 629 (1968) (upholding New York statute barring sale of "girlie" magazines to minors).

- The Supreme Court has stated that "the power of the state to control the conduct of children reaches beyond the scope of its authority over adults." Prince v Massachusetts, 321 US 158, 170 (1944). 
The unresolved nature of the relationship among the rights of minors, parents and state in this peculiar triangle is highlighted by the conflict contemplated by this Comment: a minor sues in federal court on a matter such as education, religion, morality, discipline, or other subject within the traditional scope of parental authority, and the minor's parents object to the lawsuit. ${ }^{5}$ Although at least one state court has directly addressed the issue, ${ }^{6}$ there have been no cases in the federal courts dealing directly with it; such a case could arise because of the ambiguous legal status of minors in the United States. ${ }^{7}$

Section I of this Comment provides an overview of each of the three interests involved. First, Rule 17(c) of the Federal Rules of Civil Procedure, which sets the requirements under which minors and incompetents may gain access to the federal courts, partially defines the state's role in this triangle and establishes a strong presumption in favor of protecting the legal rights of the child litigant. This section then reviews the courts' application of "adult" constitutional rights to children. Finally, the section outlines the nature of fundamental rights generally, as well as the specific origins and rationale of parental rights. The Comment recognizes that the parents' right to control their children enjoys protection as a fundamental right when asserted against the state, but argues that this protected status is inappropriate when in conflict with the child's rights.

Section II looks at the balance between the state's, the parents', and the child's rights in analogous cases involving challenges to state law requirements that minors obtain parental consent

\footnotetext{
5 This Comment does not address civil claims by the child against the parent related to matters within the traditional scope of parental control, such as "bad parenting" claims. Courts are not likely to accept such claims absent a parent's ill will. W. Page Keeton, et al, Prosser and Keeton on the Law of Torts $\$ 122$ at 909 (West, 5th ed 1984). In such claims the issue is not who controls the litigation but whether the child can state a cause of action. Furthermore, the Comment assumes that the parent is not liable for the child's litigation expenses. Granting a minor freedom to enforce her own rights does not mean that parents are obliged to provide financial support for activities of which they disapprove. See Homer H. Clark, Jr., 1 The Law of Domestic Relations in the United States 436-37 (Wèst, 2d ed 1987). This Comment also does not apply to lawsuits by minors against third parties that involve privacy issues. In privacy cases, a minor can even prevent her parents from being informed of the litigation, and possibly of the appointment of a guardian ad litem, circumventing the issue of parental control over the child's litigation. Compare Matheson, 450 US at $40 \mathrm{l} \mathrm{n}$ 5, with M.S. $v$ Wermers, 557 F2d 170, $176 \mathrm{n} 6$ (8th Cir 1977).

- See Buckholz v Leveille, 37 Mich App 166, 194 NW2d 427 (1971), discussed in note 73.

' See, for example, Gabe Kaimowitz, Legal Emancipation of Minors in Michigan, 19 Wayne L Rev 23, 26 (1972).
} 
before an abortion. Section III extends the reasoning and guidelines in these cases to the issues raised when a child attempts to sue on an issue within the traditional scope of parental control and the parents oppose the suit.

The Comment proposes that, even when the lawsuit touches on an issue normally within parental discretion, if the child can establish that she is mature and understands the nature and consequences of her decision, courts should not allow the opposing views of parents to interfere with the minor's pursuit of a legal claim. If the minor cannot establish her maturity, then the court, with appropriate consideration of the parents' views, should resolve the issue based on whether the lawsuit is in the child's best interests. This proposal provides appropriate protection of the rights of minors who are sufficiently mature to make decisions independent of their parents without ignoring the substantial parental and state interests.

\section{A Peculiar Triangle of Rights}

A. Rule 17(c): The State's Vehicle for Balancing Parents' and Children's Rights in Litigation

One side of the triangle of rights identified above is the state's interests both in promoting parental authority and in protecting the constitutional rights of its minor citizens. Rule 17(c) of the Federal Rules of Civil Procedure defines the state's procedural role:

Whenever an infant or incompetent person has a representative, such as a general guardian, committee, conservator, or other like fiduciary, the representative may sue or defend on behalf of the infant or incompetent person. An infant or incompetent person who does not have a duly appointed representative may sue by a next friend or by a guardian ad litem. The court shall appoint a guardian ad litem for an infant or incompetent person not otherwise represented in an action or shall make such other order as it deems proper for the protection of the infant or incompetent person. ${ }^{8}$

${ }^{8}$ FRCP 17(c). Although this Comment is framed by the Federal Rules and is therefore limited to cases brought in federal court, the analysis and proposals also apply to state courts whose rules of civil procedure for representation of infants and incompetents are similar to Rule 17(c). For example, the court in Wermers noted that South Dakota law (SD Cod Laws § 26-1-3 (1976)) is substantially identical to Rule 17(c). Contrast California (Cal 
This rule provides access to the court system for individuals who are denied legal capacity on grounds of infancy or incompetency under state law. ${ }^{\circ}$ The rule allows a child or incompetent to sue or be sued when accompanied by an adult representative (a guardian ad litem or next friend). ${ }^{10}$ The rule does not require the court to appoint a guardian ad litem for every minor. The court must be satisfied that the child gave her permission for the suit and that the next friend is acting in good faith and in the child's best interests. ${ }^{11}$

Nothing in the language of the rule requires parental consent to a child's lawsuit or to the appointment of a guardian ad litem. ${ }^{12}$ Presumably, however, a court could address the parents' opposition to a child's lawsuit when considering whether the child requires an adult representative to manage the litigation. Parents could enter the litigation at this point in two ways: they could intervene and oppose the adult representation that the court would otherwise deem appropriate,$^{13}$ or they could petition the court to

Civ Proc Code $\$ 373$ (West 1980)) and New York (NY CPLR 1202 (McKinney 1981)), which make distinctions based on age.

${ }^{2}$ FRCP 17(b). State law governs the issue of capacity. However, state rules governing appointment of a guardian ad litem or next friend for a minor plaintiff that conflict with the federal rule need not be applied in federal court because they are merely procedural. See Wermers, 557 F2d at $174 \mathrm{n} 4$.

${ }^{10}$ This is true even when the next friend is unrelated to the child represented and becomes involved in the litigation to attempt to establish constitutional precedent. See, for example, Ad Hoc Committee of Concerned Teachers v Greenburgh \#11 Union Free School District, 873 F2d 25 (2d Cir 1989) (committee of teachers allowed to act as next friend for their students, who were mostly wards of the state, in case asserting a constitutional right to a school environment with a racially integrated faculty); Child v Beame, 412 F Supp 593 (S D NY 1976) (New York Civil Liberties Union recruited Monroe Freedman, Dean of Hofstra Law School, to act as next friend for children in foster care to attempt to establish a constitutional right to be adopted).

"Other factors courts consider persuasive in deciding that a guardian ad litem need not be appointed include whether the minor understands the legal and personal implications of the litigation she has initiated, whether she asserts her own statutory and constitutional rights independent of her parents (for example, in challenges to pre-abortion parental consent statutes), and whether she seeks declaratory or injunctive (as opposed to monetary) relief. See Jacobs v Board of School Comm'rs, 490 F2d 601, 604 (7th Cir 1973), vacated as moot by 420 US 128 (1975); Roberts v Ohio Casualty Ins. Co., 256 F2d 35, 39 (5th Cir 1958); T.H. $v$ Jones, 425 F Supp 873, 876-77 (D Utah 1975); Baird v Bellotti, 393 F Supp 847, 850 n 5 (D Mass 1975); Foe v Vanderhoof, 389 F Supp 947, 957 (D Colo 1975); Rotzenburg $v$ Neenah Joint School District, 62 FRD 340, 341 (E D Wis 1974).

${ }^{12}$ Wermers, $557 \mathrm{~F} 2 \mathrm{~d}$ at $176 \mathrm{n}$ 6. Rule 17(c) survives virtually unchanged from Equity Rule 70 and its statutory and common law predecessors. The sparse legislative history and official commentary accompanying the rule do not discuss the hierarchy of the parents' versus the child's rights over the appointment of a guardian ad litem for the minor's lawsuit.

${ }^{13}$ Intervention is governed by Federal Rule of Civil Procedure 24. Specifically, Rule 24(a)(2) allows intervention of right where applicants claim "an interest relating to the property or transaction which is the subject of the action" and where disposition of the 
remove the appointed guardian ad litem and seek to get a new guardian appointed whose views accord with their own. ${ }^{14}$

The parents' right to intervene in either manner may depend on the type of action brought by the child. Litigation involving minors can be classified into two general groups: claims involving a financial interest, such as property and tort claims, and claims seeking relief, usually injunctive or declaratory, on matters traditionally within the scope of parental authority. For financial claims, the child's right to sue is unquestioned. At common law and today, children are legal entities separate from their parents. They are allowed, with appropriate guardianship, to hold and profit from property titled in their own name and can sue and be sued on property and tort issues. ${ }^{16}$ Thus, parental authority does not extend to the child's property rights and financial interests. ${ }^{16}$ If the parents and child have potentially competing financial interests in the litigation or if the child sues the parents on a financial matter, the parent is an inappropriate guardian ad litem because of conflicts of interest. ${ }^{17}$ In such cases, the child's right to sue and the opposing parents' inability to intervene is well settled. Rule 17(c) directs the court to ensure that another adult representative adequately protects the child's interests.

action may "impair or impede his ability to protect that interest, unless the applicant's interest is adequately represented by the parties." Courts have not required that the asserted interest be an economic one to fall within the scope of the rule. FRCP 24(a)(2). See Drummond v Fulton City Dept. of Family and Children's Services, 547 F2d 835 (5th Cir 1977); United States v Board of School Comm'rs of Indianapolis, 466 F2d 573 (7th Cir 1972); Smuck v Hobson, 408 F2d 175, 179 (DC Cir 1969). 'The nature of the parents' interest may limit the role they are allowed in the litigation. Smuck, 408 F2d at 179-80. See also Charles A. Wright, Arthur R. Miller, and Mary Kay Kane, 7C Federal Practice and Procedure $\S 1980$ (West, 2d ed 1986).

14 See Garrick $v$ Weaver, 888 F2d 687, 692 (10th Cir 1989).

18 Keeton, et al, The Law of Torts at 904 (cited in note 5).

16 A parent may serve as general guardian over the child's finances during the child's minority. This situation creates a fiduciary duty to the child that the parent must honor. See generally, Clark, 1 Domestic Relations $\$ 9.4$ at 556-68 (cited in note 5).

${ }^{17}$ See, for example, English v Miller, $370 \mathrm{~S} 2 \mathrm{~d} 968$ (Ala 1979) (possibility that children's interest in assets of father's estate may be adverse to mother's necessitates appointment of guardian ad litem); Swift v Swift, 61 FRD 595, 598 (E D NY 1973) (father could not adequately represent daughter's interests as name beneficiary of trust that father, the settlor, sought to cancel); United States v E.I. Du Pont de Nemours \& Co., 13 FRD 98, 105 (N D Ill 1952) (suit for conspiracy of restraint of trade in which minor children of adult defendants were joined as defendants and in which it appeared that a binding judgment could be entered that might dispose of or alter property rights of the minors creates a conflict of interest necessitating appointment of guardian ad litem); Marlin v Texas Co., 26 F Supp 611, 614 (N D Tex 1939), rev'd on other grounds, 109 F2d 305 (5th Cir 1940) (minor remainderman's father not competent to act as next friend for minor for purposes of divesting title out of minor). 
When the child sues a third party to vindicate nonfinancial rights within the scope of parental authority, however, whether the parent should be disqualified from serving as guardian ad litem is less obvious. ${ }^{18}$ In most cases, a parent, as general guardian, serves as the child's representative in litigation. If a guardian ad litem is appointed by the court, however, the parent can no longer control the litigation as next friend. ${ }^{19}$ Moreover, consistent with Rule 17(c)'s mandate to the court to make "such other order as it deems proper for the protection of the infant," even a minor with an active parent may sue by next friend or guardian ad litem if the parent refuses to act or if, as in financial cases, the parent's interests conflict with those of the infant. ${ }^{20} \mathrm{~A}$ parent intent on frustrating a minor's attempt to litigate would not seem to meet the criteria for guardians ad litem set by decisions construing Rule 17(c).

In deciding whether and whom to appoint as a guardian ad litem, the court should focus on the interests of the child. ${ }^{21}$ By the terms of Rule 17(c), if a child brings a lawsuit and the parents do not object, the only issue before the court is what form of adult representation the child requires to protect her interests in the litigation. The court can allow the child to proceed by next friend, guardian ad litem, or by any other adult representative deemed appropriate by the court. If the parents do object to the child's lawsuit, their goal would be to block the litigation from proceeding. The key issue is whether parents, by virtue of their right to control

18 In Wermers, 557 F2d at 175, the Eighth Circuit equated financial and moral conflicts between a parent and child and concluded that either conflict disqualifies the parent from serving as guardian ad litem and from interfering with the decision to litigate. Wermers does not control the issues addressed in this Comment because it involved a minor's right to obtain contraceptives without parental consent, a privacy issue. In privacy cases, parents should not even be informed of the litigation because notification would nullify the child's asserted privacy interest before the court has the opportunity to evaluate it. See also note 5 . Nor does Developmental Disabilities Advocacy Center, Inc. v Melton, 689 F2d 281 (1st Cir 1982), resolve the issue in this Comment. In that case, the court upheld the selection of parents as substitute decisionmakers for the named plaintiffs, who were mentally incompetent, and allowed the parents to block a lawsuit by a next friend on behalf of their children, absent evidence that the parents abused their discretion in opposing the litigation. The holdings in these cases are consistent with courts' general recognition and protection of the individual rights of mature minors, while allowing parental judgment to serve as a proxy for the rights of immature minors or incompetents if not inconsistent with the minor's best interests. See text at notes 67-71.

10 Garrick, 888 F2d at 692 .

${ }^{20}$ Id. Even parents must meet the criteria of Rule 17(c) to be appointed; their appointment is not automatic. Under Rule 17(c), a minor can also sue by an unrelated next friend or guardian ad litem. Developmental Disabilities Advocacy Center, 689 F2d at 285.

${ }^{21}$ Adelman on behalf of Adelman $v$ Graves, 747 F2d 986, 989 (5th Cir 1984); Noe $v$ True, 507 F2d 9, 12 (6th Cir 1974). 
their children, can prevent the appointment of a guardian ad litem or deny anyone else the role of next friend. To rebut the presumptions that their child can sue and that some adult representative should be appointed or recognized by the court under Rule 17(c), the parents would have to demonstrate that their right to control the child trumps the child's independent interest in the litigation. As will become clear, that may be difficult to establish.

\section{B. Children's Rights}

The independent rights of the child comprise the second side of the triangle of rights. The Supreme Court has extended constitutional rights to children only after carefully considering and overruling the interests of the parents and/or the state in retaining control over a particular right on behalf of the minor. Therefore, at least when the child asserts a constitutional right previously extended to children, the conflict in the triangle of rights between the child, parents, and state has already been settled in favor of the child.

A threshold question is why the rights of the child should be different from the constitutional rights available to adult members of society. One classic rationale is that it is proper to limit a child's freedom of independent choice in those matters with potentially serious consequences if the child chooses badly. This explanation reflects the notion that children are particularly likely to make bad choices because they lack experience, maturity, perspective, and judgment on many issues. ${ }^{22}$ An alternative but related rationale is that parental and state interests are in fact consistent with the independent interests of the child. ${ }^{23}$

The Supreme Court has recognized full constitutional rights for minors when, because of the character and importance of the child's underlying interest, the Court will not risk relying on the presumptions that the interests of the parents and the state are consistent with the child's interests or that the child is too immature to make an independent, informed decision. For example, in In re Gault, ${ }^{24}$ the Court rejected the claim that because the state is acting as parens patriae or in loco parentis, due process procedures are not required in criminal juvenile proceedings. ${ }^{25}$ The lower court

${ }^{22}$ Bellotti v Baird, 443 US 622, 635 (1979).

${ }^{23}$ Parham $v$ J.R., 442 US 584 (1979) (parents have dominant role in voluntary decision to commit a child to psychiatric hospital); see also notes 3-4.

${ }^{24} 387$ US 1, 16-18 (1966).

${ }^{25}$ See also In re Winship, 397 US 358 (1970) (due process clause requires that juvenile 
could not presume that its interests in "saving" the child are consistent with the child's interests in avoiding the stigma of being labeled delinquent. Similarly, in Bellotti $v$ Baird, ${ }^{26}$ the Court held that a mature minor has the right to obtain an abortion, rejecting the state's emphasis on the parents' interest in guiding their children and the state's interest in protecting children and promoting parental authority. ${ }^{27}$

Children's rights extend to many areas of the law that also implicate parental rights to control their children, particularly in the areas of education, religion, morality, and discipline. Courts have extended these rights to children after consideration of potential conflicts with the parents' and the state's interests in regulating the behavior of minors-the child's right is protected to the extent that the child's independent interests either do not conflict with or are more important than parental or state interests. When the Supreme Court in Belotti extended the right to obtain an abortion to minors, the exercise of the right was conditioned on a judicial finding of maturity or best interests. A minor's mature decision or her best interests therefore are more important than state or parental concerns. Thus, when parents and child disagree on whether or how the child should exercise an existing right, precedent recognizing the child's independent constitutional right indicates that the child's rights have already been determined to supercede the parents' and the state's interests in controlling the child. ${ }^{28}$ In such a case, parental interference with the litigation should be denied.

\section{Legal Status of Parents' Rights to Control Their Children}

The parents' right to control the child is the third side of the triangle of rights at issue when a minor child sues on an issue

\footnotetext{
charged with act that would be crime if committed by adult be tried under proof beyond a reasonable doubt standard); Breed $v$ Jones, 421 US 519 (1975) (prosecution of minor as an adult after juvenile court adjudication violates double jeopardy). But see McKeiver v Pennsylvania, 403 US 528 (1971) (jury trial not constitutionally required in juvenile court proceeding).

${ }^{26} 443$ US 622 (1979).

${ }^{27}$ See also Ohio v Akron Center for Reproductive Health, Inc., 110 S Ct 2972 (1990) (upholding state law requiring notification of one parent); Hodgson $v$ Minnesota, $110 \mathrm{~S} \mathrm{Ct}$ 2926 (1990) (state law requiring notification of both parents unconstitutional); Akron $v A k$ ron Center for Reproductive Health, Inc., 462 US 416, $439-40$ (1983) (upholding city ordinance requiring parental consent for minor's abortion).

28 The above analysis does not support the child's argument when she seeks to have a right extended to children as to which the competing interests of parent and state have not yet been addressed by the courts.
} 
within the traditional scope of parental authority. In order to block such a lawsuit, a parent must show that her right to control her child is strong enough to trump both the state interest in appointing a neutral representative to allow the child to sue and the child's interest in her constitutional rights. This section reviews the origins and limits of the fundamental right of parental authority over children to determine whether the parental interests should receive elevated, fundamental protection when in conflict with the rights of a minor child. It concludes that case law and commentary support recognizing parental rights as warranting fundamental protection only against outsiders, generally in the form of state intrusion into family relations, and not when in conflict with the independent rights of a child seeking to defend her own constitutional rights against a third party. While parental rights do not disappear when in conflict with the rights of the child, they should not receive the elevated status of a fundamental right.

1. Origins and limits of parental rights.

It is readily accepted that courts will enforce rights enumerated in the Constitution and amendments. There is less consensus on the question whether unenumerated rights should be recognized and similarly enforced, ${ }^{2 \theta}$ but the Supreme Court, under the doctrine of substantive due process, has labeled certain unenumerated rights "basic in our system of jurisprudence" 30 and "so rooted in the tradition and conscience of our people as to be ranked as fundamental." ${ }^{31}$ Courts review legislation that intrudes on these fundamental liberties with strict scrutiny. ${ }^{32}$ The state may intrude upon fundamental rights only to accomplish compelling objectives and it must choose means narrowly tailored to achieve the stated objective. $^{33}$

Although the Court has not clearly explained the source and limits of fundamental rights, it has explicitly relied on several principles to identify these rights, such as "the traditions and conscience" of society ${ }^{34}$ and basic values that underlie our society. ${ }^{35}$

20 See, for example, Michael H. v Gerald D., 491 US 110 (1989), citing Moore v East Cleveland, 431 US 494, 502 (1977). See also Robert H. Bork, Neutral Principles and Some First Amendment Problems, 47 Ind L J 1 (1971).

so In re Oliver, 333 US 257, 273 (1948).

31 Griswold v Connecticut, 381 US 479, 487 (1965) (Goldberg concurring).

32 See, for example, Shapiro v Thompson, 394 US 618, 634-38 (1969).

ss Id at 634 .

ss Griswold, 381 US at 493 (right to privacy).

ss Id at 499 (Harlan concurring); Poe v Ullman, 367 US 497, 522 (1961) (Harlan dis- 
Among unenumerated rights identified as fundamental are freedom of association, ${ }^{36}$ the right to interstate travel, ${ }^{37}$ the right to privacy or personal autonomy,,$^{38}$ and the right to vote. ${ }^{39}$

The rationale for classifying parental rights as fundamental is the natural law presumption that parents have innate affection for their children and are the adults most able to determine the child's best interests and the means of protecting those interests. ${ }^{40}$ Alternatively, the Supreme Court has described parental rights as rooted in the Fourteenth Amendment's grant of liberty to the parents. ${ }^{41}$

The Court first recognized parental rights during the first half of this century in cases involving parents' challenges to state regulation of the education of their children. In these cases, the Court upheld the liberty interest of the parents under the Fourteenth Amendment against state interference with foreign language training ${ }^{42}$ and with the choice of parochial or private schools. ${ }^{43}$ More modern cases also show respect for the preeminent position of parents as head of the family unit and suggest a general judicial prohibition against state interference in parental control over their children. ${ }^{44}$

Yet recent decisions also indicate that there are limits to the protected status of parental rights. Where the asserted state interest is strong, parental rights are protected only if their interest is also based on a fundamental right. In Wisconsin v Yoder, for example, the Court overturned the convictions of parents who refused to comply with the state's compulsory education law because

senting); John E. Nowak, Ronald D. Rotunda, and J. Nelson Young, Constitutional Law 370-71 (West, 3d ed 1986).

${ }^{36}$ NAACP v Alabama ex rel Patterson, 357 US 449, 460-61 (1958).

37 Shapiro, 394 US at 630.

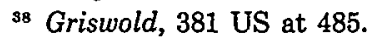

${ }^{38}$ Harper $v$ Virginia State Board of Elections, 383 US 663, 670 (1969).

10 See Parham, 442 US at 601-04, and cases cited therein. Although the language, precedents cited for support, and holding in Parham recognize strong parental rights, the case does not explicitly characterize parents' rights as fundamental.

${ }^{41}$ Santosky v Kramer, 455 US 745, 753-54 (1982); Clark, 1 Domestic Relations at 572 (cited in note 5).

42 Meyer $v$ Nebraska, 262 US 390 (1923) (striking down a state law forbidding the teaching of any modern foreign language in any private or public school to students who had not yet passed the eighth grade).

4s Pierce v Society of Sisters, 268 US 510 (1925) (state may not interfere with parents' choice to educate their children in parochial or private schools by requiring that students attend only public schools between the ages of eight and sixteen).

". See, for example, Wisconsin v Yoder, 406 US 205, 232 (1972); Santosky, 455 US at 758. 
their objection was based on religious grounds. ${ }^{48} \mathrm{~A}$ parental objection based solely on moral grounds would not be sufficient. ${ }^{46}$ Moral grounds, philosophical and personal ethical choices, do not rise to the status of a religious belief qualifying for protection under the First Amendment. ${ }^{47}$

Thus, the liberty interest of parents in controlling their children is not absolute. The Constitution does not protect parents' rights if the parents are guilty of neglect or abuse. Moreover, the state may intrude in the parents' traditional domain if a significant governmental interest supports the intrusion..$^{48}$ States now actively regulate many aspects of the parent-child relationship through, for example, compulsory school attendance laws, vaccination requirements, and child labor laws.

2. Parental rights in conflict with the child's independent rights.

One commentator suggests that the Supreme Court's characterization of parental rights as fundamental is based on the idea that parents need these legal rights to protect their children and promote their best interests against outside intrusion. ${ }^{49}$ When parental rights are asserted not to protect the child but rather to promote parental interests that conflict with the independent legal rights of the child, this rationale no longer applies, and parental rights should no longer be regarded as fundamental. Either of two alternative views of parental rights supports this conclusion that parental rights are not fundamental when asserted against the child's claimed constitutional rights. ${ }^{50}$

45406 US 205, 236 (1972). The Supreme Court's recent decision in Employment Division v Smith, 110 S Ct 1595, 1599-1602 (1990), interprets Yoder as requiring a "hybrid" claim to overcome a law of general applicability. A hybrid claim in Yoder, for example, would be the right to religious freedom in conjunction with the parent's rights to control the child's education. This interpretation seems inconsistent with express language in the Yoder opinion stating that parents have no right to evade state regulation of their children's education for reasons less compelling than the assertion of freedom of religion, suggesting that the state need not defer to parental rights alone in this context. See Michael W. McConnell, Free Exercise Revisionism and the Smith Decision, 57 U Chi L Rev 1109, 1120-21 (1990).

to Yoder, 406 US at 215-16; Clark, 1 Domestic Relations at 576 (cited in note 5).

17 Yoder, 406 US at 215-16.

48 Halderman by Halderman v Pennhurst State School \& Hosp., 707 F2d 702, 709 (3d Cir 1983), rev'd on other grounds, 465 US 89 (1984).

40 Lawrence P. Wilkins, Children's Rights: Removing the Parental Consent Barrier to Medical Treatment of Minors, 1975 Ariz St L J 31 (1975).

so Francis B. McCarthy, The Confused Constitutional Status and Meaning of Parental Rights, 22 Ga L Rev 975, 1016 (1988). 
One view of parental rights is that they are fundamental only when asserted against state intrusion and are not fundamental when asserted against the child, because these latter cases are purely private disputes. ${ }^{51}$ Under this analysis, parental rights receive protected status only when asserted against outsiders. Indeed, parental rights cases have mainly involved claims against state intrusion, not conflicts between the parents and the child. These cases can be viewed as derivative suits where the parents' claim is in fact based on the child's constitutional claims against the state. If the child's views were to conflict with those of the parents, the derivative suit analogy suggests that the child's views would be dispositive. ${ }^{52}$ In Prince $v$ Massachusetts, ${ }^{63}$ for example, the Court held that the guardian's interest must yield to state regulation barring a nine-year-old minor from selling merchandise on the streets. Despite the guardian's argument that the conviction violated her own and the child's First Amendment rights because the child was selling religious pamphlets, the Court stated, "Parents may be free to become martyrs themselves. But it does not follow [that] they are free, in identical circumstances, to make martyrs of their children before they have reached the age of full and legal discretion when they can make that choice for themselves." ${ }^{4}$ Prince can be read as a limitation on the rights of parents to oppose the interests of their children, even before the child is old enough to express an independent will. ${ }^{55}$ This limitation implies that, had the child been of a mature age, the child's-not the parent's-choice on grounds of religious freedom would be dispositive. Only the child's religious freedom would trump the state's interest.

s1 Some commentators argue that the line between state intrusion and private disputes is unclear. The above discussion draws the line based on common law rights of minors and parents, classifying any deviation as state intrusion. One could characterize allowing a minor to sue over a parent's objection as state intrusion if this common law baseline is disregarded and the background rule included complete parental authority over their children. See generally Cass R. Sunstein, Constitutionalism After the New Deal, 101 Harv L Rev 421 (1987).

Even if allowing a minor to sue constitutes state intrusion, however, the intrusion is justifiable because it is narrowly tailored to achieve a compelling justification. Allowing another citizen, even a minor, to assert her independent constitutional rights would appear to be a compelling state justification for overriding parental authority on this issue. The Rule 17(c) framework also seems to be a narrowly tailored means of preserving minors' access to the courts.

${ }^{52}$ See, for example, FRCP 23.1.

s3 321 US 158 (1944).

st Id at 170.

${ }^{85}$ Andrew Jay Kleinfeld, The Balance of Power Among Infants, Their Parents and The State, 5 Family L Q 64, 104 (1971). 
Justice Douglas's partial dissent in Yoder expresses an idea similar to this interpretation of Prince. Douglas thought the case should be viewed as a suit by the child against the state, making the issue of whether children should be required to attend high school under the state's compulsory education law in violation of their religious faith not within the dispensation of the parents alone. "It is the student's judgment, not his parents', that is essential if we are to give full meaning to what we have said about the Bill of Rights and of the right of students to be masters of their own destiny." "66 If parental rights must yield to the independent legal rights of the child, the presumptions established in favor of the child litigant under Rule 17(c) may not be rebutted by the parents' assertion of control over their child.

A second view of parental rights is that they are more accurately denominated "family rights," that is, rights possessed not by individuals, but by the family as a unit. ${ }^{67}$ In addition to being constitutionally suspect, this phrasing seems merely to couch parental control in ostensibly neutral terms. As Justice Douglas said in Yoder, "[T] he parents, absent dissent, normally speak for the entire family." 58 Dissent within the family destroys the expected supremacy of parental authority over the child. Where a dispute places the legal rights of the parents and the child in direct opposition and fractures the family structure, the family should no longer be treated as a unit with a parent as its spokesperson; rather, the child should be able to assert her constitutional rights independent of parental consent. ${ }^{59}$ Parental rights in such a case are no stronger than the child's and are not entitled to the same special deference accorded to parental interests in disputes against the state or other outsiders. ${ }^{60}$

Either of the above views of parental rights suggests sharply curtailing parents' ability to block their child's litigation. If parental rights are not fundamental when opposed to the rights of the child, then the parents will not be able to overcome the presump-

se 406 US at 245 (Douglas dissenting). Justice Douglas's solution to remand for the child's opinion has also been utilized by state courts faced with lawsuits seeking judicial consent for medical care where a third party believes the treatment is necessary but the child's parents object to the treatment, usually for religious reasons. See In re Green, $448 \mathrm{~Pa}$ 338, $292 \mathrm{~A} 2 \mathrm{~d} 387,392$ (1972), appeal after remand $452 \mathrm{~Pa} \mathrm{373,307} \mathrm{A2d} 279$ (1973); In re Seiferth, 309 NY 80, 127 NE2d 820 (1955).

${ }^{87} \mathrm{McCarthy}, 22 \mathrm{Ga} \mathrm{L} \mathrm{Rev}$ at 1016 (cited in note 50).

s8 Yoder, 406 US at 244 (Douglas dissenting) (emphasis added).

so McCarthy, $22 \mathrm{Ga} \mathrm{L} \mathrm{Rev} \mathrm{at} 1009$ (cited in note 50).

so Id at 1016. Supreme Court decisions invalidating state statutes that require parental consent as a prerequisite for a minor to obtain an abortion lend support to this theory. See text at notes $61-71$. 
tions that Rule 17(c) and the child's own constitutional rights create in favor of the child litigant.

\section{Minor's Autonomy versus State and Parental Authority}

This section examines cases involving challenges to state laws requiring parental notification or consent for a minor seeking an abortion. These cases establish the framework for the proposal that follows, which recommends that if the minor is mature, her wishes should override any parental opposition, and if the minor is immature, her best interests should govern the outcome.

\section{A. Parental Consent Statutes}

Challenges to state laws requiring parental notification or consent for minors seeking an abortion present a close analogy to the conflict created when a child brings a lawsuit on an issue normally within parental control. ${ }^{61}$ These cases set up a two-tier rule that distinguishes the rights of mature minors from those of immature minors, and implicitly vindicates the child's right to be free from parental veto power over the exercise of her constitutional right to an abortion.

Several similarities exist between the abortion cases and the issue presented when a minor asserts the right to sue on an issue normally within the scope of parental control. In both situations the child must appeal to the state in order to exercise her independent constitutional rights without the cloak of parental support. In both cases a professional represents or advises the minor. And in both situations the state and the parents may be legitimately interested in protecting the child from unethical practitioners. ${ }^{62}$

61 But see Clark, 1 Domestic Relations at 577 (cited in note 5) (abortion cases not relevant to the question of whether a child has a constitutional right to make decisions in opposition to his parents). Clark suggests that the parents' judgment should be decisive in matters where there is no harm to the child. His position presupposes a definition of harm that must not include deprivation of a child's constitutional rights. This Comment defines harm to include a denial of access to the legal system for protection of legal rights.

${ }^{62}$ In the decision to litigate there is the concern that the child serves as a plaintiff for some third party more interested in establishing precedent than in protecting the child's best interests. Child v Beame, 412 F Supp 593 (S D NY 1976). This Comment proposes that parents should be notified of any suit by their child (except those implicating privacy, see note 5) and allowed at a minimum to ensure that the lawsuit is the child's own decision and not the result of undue influence. See M.S. $v$ Wermers, 557 F2d 170, 178 (8th Cir 1977) (Henley dissenting). 
Under the umbrella of the right to privacy, Roe $v$ Wade ${ }^{63}$ established a woman's constitutional right to an abortion, subject to regulation by states after the first trimester of pregnancy. Courts extended the right to privacy to minors shortly thereafter. ${ }^{64}$ After Roe, states tested the limits of permissible regulation of abortion. Some states' regulations included parental consent and notification requirements for abortions by a minor. These states reasoned that the constitutional rights of children are not as extensive as those of adults, and that the state has a compelling interest in regulating the activities of minors because of their vulnerability and lack of mature judgment. ${ }^{65}$ Consistent with this rationale, the Supreme Court has recognized that states have a legitimate interest in encouraging parental involvement in the abortion decision of a minor child and in promoting and protecting parental authority in child rearing. ${ }^{66}$

Nevertheless, in every case involving challenges to state statutes requiring one or both parents to consent before a minor may obtain a legal abortion, the Court has required a legal alternative to parental consent. ${ }^{67}$ In Planned Parenthood of Central Missouri $v$ Danforth ${ }^{68}$ the Court first held that states may not impose a blanket requirement of parental consent upon an unmarried minor to obtain an abortion during the first trimester of pregnancy. Under the principles established in Roe, the state cannot, absent a significant governmental interest, grant a third party an absolute veto over a woman's otherwise legal abortion decision. The Court rejected the asserted interest in promoting parental authority and held that any interest the parents might have in the child's abortion decision is at most equal to the mature minor's right to privacy. ${ }^{69}$

Thus, states seeking to regulate minors' access to abortions and to promote parents' involvement in the abortion decision must provide an alternative authorization procedure..$^{70}$ The bypass procedure the Court suggested in Bellotti $v$ Baird is an expedited, confidential judicial proceeding. Under this procedure, the court

os 410 US 113 (1973).

ot See, for example, Foe $v$ Vanderhoof, 389 F Supp 947, 953-54 (D Colo 1975).

as See Bellotti, 443 US at 640-41; Planned Parenthood of Central Missouri v Danforth, 428 US 52, 91 (1976) (Stewart concurring).

68 Bellotti, 443 US at 634.

or The Court upheld a Utah statute requiring that the parents of a minor seeking an abortion be notified if possible in H.L. $v$ Matheson, 450 US 398 (1981). However, that decision was expressly limited to immature dependent minors. The plaintiff in that case also did not present any evidence that an abortion was in her best interests. Id at $401 \mathrm{n} 3$.

os 428 US 52 (1976).

60 Id at 75.

70 Bellotti, 443 US at 643 . 
must authorize an abortion without parental consultation or consent if a pregnant minor can demonstrate her maturity and understanding of the nature and consequences of her decision to abort or if she can show that, even absent maturity, the abortion is in her best interests. ${ }^{71}$

\section{B. Application of Bellotti to the Right to Sue}

Even though states have an interest in protecting parental authority by establishing parental consent or notification requirements, the Bellotti bypass procedure subordinates these interests to those of the minor who demonstrates either her maturity or that an abortion is in her best interests. If applied to a minor's right to pursue litigation, the Bellotti approach suggests that a minor who can demonstrate her maturity, or that the litigation is in her best interests notwithstanding her immaturity, should be allowed to pursue a lawsuit even if it involves an issue normally governed by parental control.

The applicability of Bellotti to a minor's decision to litigate is disputable, however. In Bellotti, the court stated that the abortion decision is "one that simply cannot be postponed, or it will be made by default with far-reaching consequences." 2 If these criteria are strictly applied to the issue of whether a minor should be allowed to pursue a lawsuit on a matter within the traditional scope of parental authority despite parental opposition, a court would rarely feel compelled to appoint a guardian ad litem for a minor or allow the minor to pursue her lawsuit by next friend outside the abortion context. To be sure, there will be some cases where enforcement of a minor's legal rights will be restricted to a limited timeframe and bring detrimental consequences if ignored. For example, a minor student may challenge a suspension or a condition at his school that he feels violates one of his constitutional rights. ${ }^{73}$ In such a case, delay until the student reached majority would make the case moot. Although the detriment is obviously less severe than in the case of a denial of an abortion, the option to

71 Id at $647-48$.

${ }^{22}$ Id at 643 .

${ }^{73}$ See Buckholz, 194 NW2d at 429, in which a sixteen-year-old minor sued his local school board to challenge the constitutionality of the school's dress code dictating maximum hair length for boys. His parents approved of the dress code and disapproved of the boy's lawsuit. The court ruled that the boy could proceed with the suit despite his parent's opposition, reasoning that no parent-child conflict existed because the parents had declined to exercise control over the minor by regulating his hair length to conform to the school board rule. 
force a change in the child's school environment through litigation, like the option to have an abortion, would no longer be available to the minor. But few, if any, litigation decisions involve consequences such as those at stake in Bellotti. As the Court stated, there are "few situations in which denying a minor the right to make an important decision will have consequences so grave and indelible" as the abortion decision. ${ }^{74}$

Although deprivation of certain constitutional rights may not have the severe impact of being a teenage mother, the Constitution guarantees particular rights because of a collective belief that these rights should be inviolable and that violation of them results in harm to the individual and society. Limiting a minor's ability to protect these rights to situations where her parents are in accord would make the extension of constitutional rights to minors almost meaningless. A minor's right to vindicate her constitutional rights through the courts should not be limited to issues like abortion that are time-critical and potentially detrimental.

Indeed, the argument for allowing children access to courts to vindicate their rights is actually stronger than the rationale for creating bypass procedures under Bellotti. In Bellotti, the statute defining the relative rights of minors and parents created a baseline of promoting parental authority and limiting the minor's constitutional right. The Bellotti Court's emphasis on the special nature of the abortion decision was a justification for its departure from this statutory framework.

Rule 17(c), on the other hand, contains no reference to parental rights over the child's litigation decision-the only limits on a minor's right to sue are the requirements of adequate representation and protection of the child's interests. In the Rule 17(c) context, then, there is no need to justify allowing a minor to bypass the statute because the statutory presumption runs in favor of the child. A child must therefore be able to vindicate her constitutional rights in court in the face of parental opposition upon a showing of maturity or that the litigation is in her best interests.

It is important to note that this conclusion transcends the abortion decisions. Even if Roe $v$ Wade were overturned, the relationship between children's, parents', and states' rights set out in the parental consent cases would remain valid. These cases establish the principle that, despite both minors' reduced capacity to make important decisions and the states' legitimate interest in en-

74443 US at 642. 
couraging parental involvement in their minor child's important decisions, state and parental interests must accede to the rights of a mature minor or of an immature minor whose best interests are not served by parental veto power.

\section{Criticism}

The proposal outlined above can be fairly criticized as placing a potentially severe burden on parents whose children decide to assert their constitutional rights in litigation against the parents' better judgment. Although, as argued above, parental rights to control their children cannot be deemed fundamental when the child seeks to enforce a constitutional right against a third party, one could plausibly argue that neither the framers of the Constitution and the Bill of Rights nor the drafters of Rule 17(c) intended to destroy the family structure by recognizing minors' constitutional rights and allowing them access to the courts. Due to the limited powers of a guardian ad litem or next friend, the mere appointment of such a representative for the child may not be a significant intrusion into parental authority; however, the litigation and satisfaction of the minor's legal claims may be, depending on the nature of the right asserted.

For example, in Yoder, Justice Douglas suggested that the students' opinions be solicited and that their wishes as to whether or not to attend high school may be dispositive. ${ }^{75}$ If this suggestion were followed and one or more of the students chose to attend high school, the court would be placed in the awkward position of enforcing the judgment. The decision, as well as the process of challenging the minor's right to pursue the litigation initially, might cause the breakdown of family relations to the point that the children would have to live with a foster family. These considerations are taken into account from the child's (though not the parents') point of view in the assessment of best interests and maturity. In all cases, the process of challenging a child's chosen guardian ad litem may be a significant financial burden for the parents if legal counsel is engaged.

However, the federal courts' power under Rule 17(c) to appoint a guardian ad litem for a minor plaintiff or to allow the minor to sue by next friend or with other adult representation in op-

75 Yoder, 406 US at 242 (Douglas dissenting) ("if an Amish child desires to attend high school, and is mature enough to have that desire respected, the state may well be able to override the parents' religously motivated objections"). 
position to the wishes of the parents can be a narrow intrusion into parental authority over the child. A guardian ad litem or next friend does not replace the child's parents or general guardian for other functions. The purpose of the position is merely to control the litigation for the minor by engaging counsel, filing suit, etc. ${ }^{76}$ If the courts allow minors the right of self-determination in their right to sue, the breakdown of the family unit does not necessarily follow. ${ }^{77}$ Gaining the power of decision over their own lives is part of the process of maturation for the child that parents should welcome and encourage, or at least accept. Making the option available will not induce the mass of minors to exercise it. Just as it is natural for parents to care for their children, so too it is natural for children to turn to their parents for guidance. ${ }^{78}$ Even if parents lose in their attempt to be appointed as guardian ad litem for the child or to block the appointment of another, they can still participate in the litigation as it progresses through intervention by right or by the court's permission under Rule 24 of the Federal Rules of Civil Procedure. ${ }^{79}$

\section{A Two-Tier Test: Maturity or Best Interests}

This section describes the two-part inquiry introduced above to resolve the conflict posed by a minor's lawsuit that touches on an issue normally within parental discretion. First, a child can sue despite her parents' opposition if she establishes that she is mature. Second, even if the child fails to establish maturity, she can sue upon a showing that the suit is in her best interests, with appropriate input from the parents and the child's attorney. In order to reveal how this proposal would work in practice, this section explores the meanings of the often interrelated concepts of maturity and best interests.

\footnotetext{
76 Noe v True, 507 F2d 9 (6th Cir 1975).

${ }^{77}$ A 1984 survey compared the percentages of teenagers who inform their parents that they were considering abortions in Minnesota, which has a notification law, with those in Wisconsin, which does not. In both states approximately $60 \%$ of teenagers told their parents of their decision. Linnet Myers, Pregnant Teens Face Parents-Emotions Strong over Requiring Notice Before Abortion, Chicago Tribune 1:1 (July 5, 1990). Similar statistics were noted in a comparison of parental involvement in Massachusetts, which requires minors to obtain the permission of both parents or a judge, and Connecticut and New Hampshire, where no such consent is required. In all three states, about $75 \%$ of girls who had abortions shared the decision with their parents. Margaret Carlson, Abortion's Hardest Cases, Time 22 (July 9, 1990).

78 Wilkins, 1975 Ariz St L J 31, 70-71 (cited in note 49).

79 See note 13 .
} 


\section{A. Assessing Maturity}

The Supreme Court has not offered a comprehensive definition of maturity, but it did suggest in Bellotti that maturity implies the capacity to make informed and intelligent decisions independent of parental consent or consultation..$^{80}$ Psychiatrists have identified five key elements of the ability to give fully informed consent: access to relevant information, capacity to understand, actual understanding (including ability to anticipate possible outcomes and consequences of the decision), freedom to choose, and ability to make a reasoned choice and express it clearly. ${ }^{81}$

Thus, a minor's ability to make mature decisions necessarily varies with the subject matter of the decision. An analogous assessment of maturity is applied under mature minor rules operating in some states. ${ }^{82}$ Under these rules, a minor who is mature enough to understand the nature and consequences of medical treatment may consent to the treatment. ${ }^{83}$ Contrary to the Court's logic in Bellotti, mature minor rules generally limit the minor's capacity to consent to those situations in which the proposed treatment does not create a serious risk to the child's life or health-to decisions that are neither critical nor time-dependent. ${ }^{84}$

Consistent with the approach of these rules, the court should consider the minor's capacity to comprehend the subject matter of the litigation in determining maturity. As in the procedure established in Bellotti, the minor would carry the burden of establishing maturity. The type of right asserted will play a large role in guiding the court's determination of maturity. In each situation, the court should assure itself that the minor understands the possible consequences and is mature enough to pursue the litigation and to handle its aftermath. Some cases will be more complex in this regard, and it will thus be more difficult for the minor to establish maturity. In cases like Yoder (as characterized by Justice Douglas),

so 443 US at 647.

81 See Charles W. Lidz, et al, Informed Consent: A Study of Decisionmaking in Psychiatry (Guilford, 1984), cited in Gary B. Melton, ed, Reforming the Law, Impact of Child Development Research 8-9 (Guilford, 1987).

82 See, for example, Akron v Akron Center for Reproductive Health, Inc., 462 US 416 (1983), on remand 604 F Supp 1268 (N D Ohio 1984); In re Green, 452 Pa 373, 307 A2d 279 (1973); Younts v St. Francis Hospital \& School of Nursing, Inc., 205 Kan 292, 469 P2d 330 (1970); Lacey $v$ Laird, 166 Ohio 12, 139 NE2d 25 (1956) (per curiam); Gulf \& SIR Co. $v$ Sullivan, 155 Miss 1, 119 S 501 (1928); Wilkins, 1975 Ariz St L J at 49-54 (cited in note 49).

83 See, for example, Ark Stat Ann § 20-9-602 (1987); Miss Code § 41-41-3 (1972). See also Clark, 1 Domestic Relations at 581 (cited in note 5).

84 See note 82 . 
for example, where there exists a potential for the breakup of the family, ${ }^{85}$ the court should be sure that the minor is prepared to continue her education and possibly control of all other aspects of her life without family support. In contrast, a lesser showing of maturity might be sufficient in the type of case illustrated by Buckholz. Where the child is suing for the right to wear long hair, a decision in the child's favor need not disrupt basic family relations.

The court should not consider the complexity of the subject matter in isolation; rather, it should also weigh any possible adverse consequences of parental control over the subject matter. In addition to traditional mature minor rules, every state allows a mature minor to consent to treatment for critical health services relating to one or more of the following conditions: pregnancy, venereal disease, drug abuse, and mental disorders. ${ }^{86}$ The rationale for these statutes seems to be that the risk of allowing the minor to make a decision without parental supervision is outweighed by the harm to the minor from foregoing treatment for these problems. This rationale echoes the arguments discussed previously for extending certain constitutional rights to children. For example, if a juvenile wishes to sue the state for some deficiency in its procedures for handling prosecutions of minors, the child should be able to protect herself against the unwarranted and harmful stigma of a criminal conviction regardless of parental support for the appeal. In this situation, potential harm to the child from denying the right to make an "adult" decision is less than that which would result from foregoing a decision or relying on parental decisionmaking.

The inquiry into the child litigant's maturity thus requires a case-by-case determination rather than a strict age requirement. For nonprivacy issues ${ }^{87}$ creating a potential conflict between parents and child, the court should inform the parents of the appointment of a guardian ad litem, and therefore of the child's lawsuit, to give them an opportunity to participate in the appointment process. For the court to make a finding of maturity, it must assess the minor's consciousness of the nature and consequences of her litigation decision. Parental input is highly relevant and useful to this determination.

\footnotetext{
ss See text at note 56 .

so See compilation of medical consent statutes by state, type, and medical problems contained in Wilkins, 1975 Ariz St L J at 86 (Appendix C) (cited in note 49).

87 See note 5 .
} 


\section{B. Assessing Best Interests}

If a minor fails to establish maturity, she may still proceed with her lawsuit over parental objection if she can satisfy the court that the litigation is in her best interests. "Best interests" is the governing standard with regard to children in family law cases involving adoption, foster care, and custody after divorce. ${ }^{88}$ The inquiry into best interests in general family law cases is a subjective and necessarily indefinite process that can take the child's, the parents', the state's, and even the child's counsel's conception of the child's best interests into account. ${ }^{89}$ This section seeks to limit the situations in which the court must consider best interests as well as the factors relevant in making an ultimate determination on the issue.

The court must first determine whether the minor is mature. If the minor is found to be immature, courts apply the doctrine of substituted judgment, which is a means of determining best interests. ${ }^{90}$ This doctrine requires the court to consider what the immature minor would choose if she were mature, taking into account the child's expressed preference and partial competency. ${ }^{91}$ An advantage of the two-tier inquiry is that because the child's best interests are addressed only in those situations in which maturity is first ruled out, the number of cases in which the court must apply the necessarily ambiguous best interests test is limited.

The considerations relevant to establishing maturity are also relevant to the assessment of the child's best interests, assuming maturity is not found. However, courts should be careful not to collapse the two tiers; the maturity test should not decide both issues. The court should also take care that considerations of the merits of the child's position are not determinative. The maturity and best interests tests do not control whether the child will ultimately prevail, but only whether she has the right of access to a

\footnotetext{
${ }^{88}$ See Quilloin v Walcott, 434 US 246, 255 (1978).

${ }^{82}$ See generally Joseph Goldstein, Anna Freud and Albert J. Solnit, Beyond the Best Interests of the Child (Free Press, 2d ed 1979); Comment, Speaking for the Child: The Role of Independent Counsel for Minors, $75 \mathrm{Cal} \mathrm{L}$ Rev 681 (1987). In custody cases, courts determine the weight, if any, given to the child's preference based on the child's mental development and maturity. See, for example, D. $v$ Z., 414 A2d 211 (Del 1980); Re Marriage of Kuhn, 581 SW2d 112 (Mo App 1979); Lawson v Lawson, 198 Va 403, 96 SE2d 215 (1956); see generally Annotation, Child's Wishes as Factor in Awarding Custody, 4 ALR3d 1396, $\S \S 9-11$ (1965). This approach merges the determination of maturity with determination of the child's best interests and illustrates that there is no truly independent source for discovering best interests.

${ }^{\text {go }}$ Robert H. Mnookin, In the Interest of Children 225 (W.H. Freeman and Co., 1985).

o1 Id.
} 
court to determine the merits of her claim. Although the previous discussions of Rule 17(c), children's rights, and parental rights all favor this right of access, evidence of adverse effects of the litigation on the immature child could rebut this presumption.

Parental input is valuable in the inquiry into best interests because the impact of the child's litigation on continued family relations will be a significant concern of the court. Some courts have used the doctrine of substituted judgment to justify proxy decisionmaking by parents on behalf of their minor children based on the theory that parents often subordinate their needs and preferences to those of their children..$^{92}$ Although this theory does not always hold true, courts should consider the judgment of the parents as proxy for the immature child. Another factor that a court should consider is the long-term effect on the child from denial of the opportunity to assert her constitutional rights. In Yoder, for example, the court would have to balance the effects of delay in education against potential family disruption over the child's religious independence.

By hearing the views of the child and the parents before deciding whether the lawsuit is in the child's best interests, the court would correct one of the identified weaknesses of the bypass procedure established for minors to get an abortion without parental consent in Bellotti. The proceedings before the judge in the abortion decisions are uncontested; because only the minor's views are presented, the judge has little basis upon which to rule that an abortion is not in the minor's best interests. ${ }^{93}$ In the proposed hearing to determine whether an immature minor's decision to litigate is in her best interests, however, there would be no privacy barrier to prevent the court from hearing all interested parties.

\section{ConCLusion}

The language and purpose of Rule 17(c), the proper scope of parental rights to control their children, and due recognition of the independent constitutional rights of the child argue in favor of allowing a mature child to pursue a lawsuit despite parental opposition and requiring a hearing to determine whether the proposed litigation is in the immature child's best interests.

92 Melton, ed, Reforming the Law at 11-12 (cited in note 81).

${ }_{93}$ In Minnesota, a five-year study indicated that of 3,573 petitions filed by minors to obtain judicial rather than parental consent for an abortion, 3,558 were granted. Myers, Chicago Tribune at 1:2 (cited in note 77). See also Mnookin, In the Interest of Children at 263 (cited in note 90 ). 
First, Congress designed Rule 17(c) to promote and protect the ability of minor plaintiffs and defendants to pursue their legal interests with such guidance as the trial court deems necessary in the best interests of the minor. The rule reflects a belief that minors as well as adults should have access to the courts to protect their legal rights. Thus, the question whether a court should appoint a guardian ad litem or permit a minor to sue by her next friend in the face of parental opposition begins with the presumption that minors may sue.

Second, the Supreme Court has extended significant constitutional rights to minors. The Court has extended these rights to children only after considering potential conflicts with traditional parental and state control over the rights of children. Therefore, at least in cases where the child is asserting a right previously extended to children, the Court has already determined that the child's interests are superior to those of the parents or the state.

Third, although classified as fundamental by the Supreme Court, parental rights are best understood as warranting this protected status only when asserted against the state or when they coincide with the wishes of their mature child. Courts formulated the doctrine of parental authority as a device to protect minors from their own weaknesses and to promote their best interests. ${ }^{94}$ It would be illogical to bar recognition of a minor's rights to independent determination of her own self-interest under the guise of parental rights based on protection of the child's interest. Deference to parental control should not apply when minors have attained a level of moral development sufficient to make responsible decisions.

Finally, in cases involving a minor's right to obtain a legal abortion without parental consent, the Supreme Court has consistently held that states must provide a procedure to bypass parental consent for mature minors and for immature minors who can demonstrate that an abortion is in their best interests. The logic of these cases, if applied to the issue of whether a minor may conduct a lawsuit in opposition to the wishes of her parents, suggests that for mature minors the court should appoint a guardian ad litem to conduct the lawsuit despite the parents' opposition. For immature minors, the court should appoint a guardian ad litem if it finds that the lawsuit is in the child's best interests.

๑4 Wilkins, 1975 Ariz St L J at 56-57 (cited in note 49). 
Access to the courts is essential to the meaningful recognition of minors' constitutional rights. If parental approval is required for a child to seek judicial enforcement of her rights, minors' rights are mere embellishments of the state's and parents' rights to control minors. The intrusion of Rule 17(c) into family relations is narrowly defined and necessary if we are to give substantive content to the rights that the Supreme Court has extended to minors in recent years. 


$$
\text { , }
$$

